\title{
ДІАГНОСТИЧНЕ ЗНАЧЕННЯ ВИЗНАЧЕННЯ С-РЕАКТИВНОГО БІЛКА У ВІЛ-ІНФІКОВАНИХ ПАЦІЕНТІВ, ХВОРИХ НА ХГС І КО-ІНФЕКЦІЮ ВІЛ / ХГС
}

\author{
Національний медичний університет, м. Харків
}

Визначено вміст С-реактивного білка (СРБ) у ВІЛ-інфрікованих осіб, хворих на ХГС і ко-інфекцію ВІЛ/ ХГС. Дослідження СРБ проведено у 107 хворих, з них хворих на ХГС - 36, ВІЛ-інфрекцію - 35, ко-інфрекцію ВІЛ/ ХГС - 36. Встановлено достовірне підвищення вмісту СРБ у ВІЛ-інфрікованих осіб, хворих на ХГС і ко-інфрекцію ВІЛ/ХГС $(p<0,001)$. У ВІЛ-інфрікованих осіб і хворих на коінфекцію ВІЛ/ХГС не встановлено достовірного зв'язку між вмістом СРБ і клінічною стадією ВІЛ-інфрекції (p>0,05). Вміст СРБ у хворих на ХГС і ко-інфрекцію ВІЛ/ХГС з фріброзом печінки був вірогідно вище, ніж у хворих без фріброзу ( $<<0,001)$. Виявлено вищий рівень СРБ у пацієнтів із За генотипом HCV у хворих на ХГС $(p<0,05)$ і ко-інфекцію ВІЛ/ХГС $(p<0,01)$ порівняно $з 1 b$ генотипом.

Ключові слова: хронічний гепатит С, ВІЛ-інфекція, ко-інфекція ВІЛ/ХГС, С-реактивний білок.

С-реактивний білок (СРБ) був першим ідентифрікованим представником групи так званих «білків гострої фрази» (БГФ). Практично всі БГФ є нормальними складовими плазми крові, що мають різні фрізико-хімічні властивості. Характерна риса, що об'єднує ці білки в одну групу - збільшення в крові їх концентрації у відповідь на цілий ряд стимулів (інфекційні хвороби, запалення, травма, некроз, пухлинний ріст), що призводять до тканинного пошкодження. Доведено, що підвищення рівня БГФ у крові відбувається за рахунок посилення їх синтезу печінкою з розвитком так званого синдрому системної запальної відповіді [1].

Останнім часом з'являється все більше данихпро роль хронічних запальних процесів у патогенезі метаболічного синдрому (МC), інсулінорезистентності (IP), цукрового діабету (ЦД) і серцево-судинних захворювань (СС3). Синтез СРБ запускається і контролюється певними медіаторами, в першу чергу цитокінами. Доведений зв'язок між IP, рівнями інтерлейкінів (ІЛ)-1, ІЛ-6 і СРБ. Активовані цитокіни (ІЛ-1, ІЛ-6, фрактор некрозу пухлин (ФНП)- $\alpha)$ підсилюють продукцію глюкокортикоїдів, зумовлюють лейкоцитоз, збільшення шОЕ, підвищення температури тіла, зниження концентрації заліза і цинку в сироватці крові. На відміну від короткоживучих цитокінів (для яких характерні добові коливання) вміст СРБ досить стабільний завдяки його відносно тривалому періоду напіввиведення з організму $[1,2]$.

СРБ є вторинним регулятором синдрому системної запальної відповіді та імуномодулятором, який активує фрункцію клітин пухкої сполучної тканини, клітин ретикулоендотеліальної системи, а також клітин, які реалізують реакції вродженого імунітету шляхом посилення постачання їх субстратом для отримання енергії (синтезу АТФ) насиченими і ненасиченими жирними кислотами. Після секреції СРБ, маючи спорідненість до фросфоліпідів, зв'язується 3 ліпопротеїнами дуже низької щільності і циркулює 3 ними в плазмі крові та міжклітинному середовищі. Більшість лікарів і науковців розглядають СРБ як маркер запалення. Запускаючи комплемент, адгезію, хемотаксис, фрагоцитоз, модулюючи активність імунокомпетентних клітин і тромбоцитів СРБ фрактично здійснює зв'язок між різними ланками запального процесу $[3,4]$.

СРБ синтезується в основному в печінці, хоча встановлено, що цей білок можуть синтезувати нейрони, клітини нирок, моноцити, лімфоцити і макрофаги альвеол. СРБ може синтезуватися атеросклеротичними бляшками, так як рівень СРБ в них значно вище, ніж в оточуючих тканинах. Ендотеліоцити аорти людини не тільки містять мРНК СРБ, але синтезують і секретують СРБ. мРНК СРБ знайдена також і в адипоцитах людини [5].

Низкою досліджень підтверджено, що підвищений рівень СРБ пов'язаний з ризиком розвитку ЦД. Збільшення базового рівня СРБ стимулює «патологічне» фосорорилювання субстрату рецептора інсуліну та призводить до IP і гіперглікемії. Відбувається глікозування аполіпопротеїну В у складі ліпопротеїнів низької щільності, прогресування запалення в судинах, гіперліпідемія та атерогенез. Таким чином, при ЦД 2 типу збільшення СРБ є основною причиною 


\section{ОРИГІНАЛЬНІ ДОСЛІДЖЕННЯ}

гіперглікемії та відповідно IP. Відомо, що при ЦД 2 типу клітини не реагують на інсулін через порушення передачі сигналу від інсуліну, який проходить через трансмембранний інсуліновий рецептор і від нього до субстрату інсулінового рецептора. Підвищений рівень СРБ порушує передачу цього сигналу, в результаті чого знижується чутливість до інсуліну. При визначенні СРБ і глікозильованого гемоглобіну (HbA1C) у 454 пацієнтів протягом 21 місяця, у 128 осіб (28 \%) відбулося 166 судинних подій (інораркт міокарду, аортокоронарне шунтування, інсульти, смерть). Статистичний аналіз показав, що у пацієнтів з рівнем СРБ вище 4,4 мг/л і HbA1C більше ніж 6,2 \% самий високий ризик указаних патологій [6]. Так, В.В. Вельков (2008) доводить, що поєднане дослідження базового рівня НbA1C і СРБ свідчить про реальні показники гіперглікемії, тяжкість гіперліпідемії, запальні захворювання, які призводять до судинних ускладнень, тяжкість серцево-судинних ускладнень [3]. Інсулін має значну протизапальну дію, пригнічує синтез СРБ [7].

3 роками у хворих з МС і IP збільшуються сироваткові концентрації СРБ. Базова концентрація СРБ - це його рівень у практично здорових осіб. Вимірювання базового рівня СРБ має прогностичне значення, яке дозволяє оцінити ступінь ризику серцево-судинних захворювань (СС3). У цілому СРБ - це незалежний предиктор МС і СС3. За рекомендаціями американської кардіологічної асоціації визначено такі критерії оцінки співвідношення рівня СРБ і кардіоваскулярного ризику: $<1$ мг/л - ризик низький, 1-3 мг/л - ризик середній, $>3$ мг/л - ризик високий. Рівень СРБ від 3 до 10 мг/л це ознака запального процесу, що має млявий перебіг та пов'язаний з високим ризиком СС3 [8].

Нами встановлено, що у хворих на ко-інфекцію ВІЛ/ХГС спостерігаються порушення ліпідного обміну, а саме підвищення у сироватці крові вмісту тригліцеридів, коефріцієнту атерогенності (КА), ліпопротеїнів низької щільності, ліпопротеїнів дуже низької щільності і зменшення ліпопротеїнів високої щільності (ЛПВЩ) [9]. Таким чином, враховуючи виявлені порушення ліпідного обміну, ми вирішили визначити вміст СРБ у хворих на ко-інфекцію ВІЛ/ХГС, що допоможе прогнозувати ризик серцево-судинних порушень у досліджених пацієнтів.

\section{Пацієнти і методи}

Дослідження за темою роботи проводилися на кафедрі інсекційних хвороб Харківського національного медичного університету, розташованої на базі Обласної клінічної інфекційної лікарні м. Харкова, та в Харківському обласному центрі профрілактики та боротьби зі СНІДом.

У дослідження включено 107 хворих, з них 35 ВІЛінфрікованих осіб, 36 хворих на ХГС і 36 - на ко-інфрекцію
ВІЛ/ХГС. Вік хворих коливався від 20 до 63 років. 29 хворим на ХГС і 24 Хворим на ко-інфекцію ВІЛ/ХГС проводили оцінку стану печінки за системою Fibromax (Fibrotest). F0 діагностовано у 9, F1 - у 13, F2 - у 3, F3 - у 2, F4 - у 2 хворих на ХГС. У хворих на ко-інфекцію ВІЛ/ХГС FО діагностовано у 8, F1 - у 9, F2 - у 2, F3 - у 3, F4 - у 2 пацієнтів. Генотипування вірусу гепатиту C (HCV) проводилося 67 пацієнтам: 33 Хворим на ХГС і 34 на ко-інфекцію ВІЛ/ХГС. 1b генотип НCV виявлено у 20 хворих $(60,6 \%)$ на ХГС, а За - у 13 хворих $(39,4)$. У хворих на ко-інфекцію ВІЛ/ХГС 1b генотип HCV діагностовано в 14 випадках (41,2 \%), а 3а - у 20 (58,8 \%).

Клінічну стадію ВІЛ-інфекції в усіх досліджених пацієнтів установлювали згідно з клінічною класифрікацією стадій ВІЛ-інфекції у дорослих і підлітків (ВО3, 2006 р.). 2-гу клінічну стадію (кл. ст.) ВІЛ-інфекції встановлено в 11 ВІЛінфрікованих осіб і 11 хворих на ко-інфекцію ВІЛ/ХГС, 3-тю кл. ст. - у 13 і 13, 4-ту кл. ст. - у 11 і 12 пацієнтів відповідно.

Групу порівняння склали 32 практично здорові особи, які були співвідносні за віком і статтю з хворими досліджуваних груп. Зразки сироватки крові для досліджень були взяті 3 інформованої згоди пацієнтів. Дослідження проводилися згідно $з$ протоколом № 5 засідання комісії з питань етики та біоетики ХНМУ від 06.06.12 р.

Дослідження СРБ було проведено імунофрерментним методом із використанням набору реагентів фрірми "DRG-Diagnostics" (США) на імуноферментному фротоколориметрі "HUMAREADER" фрірми "Human" (Німеччина). Проводили визначення загального холестерину (3X) i лПВщ ферментативно-колориметричним методом на біохімічному аналізаторі BS-300M фрірми «Sinnowa» 3 діагностичними наборами фірми "СпайнЛаб" (Іспанія). КА розраховували за фрормулою: КА=(3Х-лПВЩ)/ЛПВЩ, де КА - коесріціент атерогенності, ум. од.; 3X - вміст 3 Х у сироватці крові, ммоль/л; лПВЩ - вміст лПВЩ у сироватці крові, ммоль/л.

Статистична обробка даних проводилася з використанням пакета прикладних програм «Statistica for Windows», 8.0. Використовувалися методи: описової статистики (визначення числових характеристик змінних - середньої арифрметичної (М), середньої помилки вибірки (m), визначення достовірності відмінностей (р)), що перевіряються за t-критерієм Стьюдента-Фішера в репрезентативних вибірках, метод кореляційних структур [10].

\section{Результати досліджень та їх обговорення}

Дані щодо вмісту СРБ у сироватці крові ВІЛінфікованих осіб, хворих на ХГС і ко-інфекцію ВІЛ/ ХГС (табл. 1), свідчать, що рівень СРБ був достовірно підвищеним у хворих усіх груп і дорівнював 3,17 мг/л у ВІЛ-інфікованих осіб, 3,87 мг/л у хворих на ХГС і 6,89 мг/л у хворих на ко-інфекцію ВІЛ/ХГС, порівняно 3

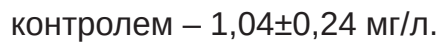




\section{ОРИГІНАЛЬНІ ДОСЛІДЖЕННЯ}

Таблиця 1

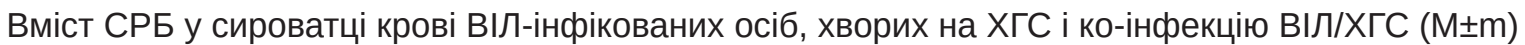

\begin{tabular}{|c|c|c|c|c|}
\hline \multirow[b]{2}{*}{ Показник } & \multicolumn{3}{|c|}{ Групи хворих } & \multirow{2}{*}{$\begin{array}{c}\text { Контрольна група } \\
(n=32)\end{array}$} \\
\hline & $\begin{array}{c}X \Gamma C \\
(n=36)\end{array}$ & $\begin{array}{c}\text { ВІЛ-інсрекція } \\
(\mathrm{n}=35)\end{array}$ & $\begin{array}{c}\text { Ко-інфрекція ВІЛ/ХГС } \\
(n=36)\end{array}$ & \\
\hline СРБ, мг/л & $\begin{array}{c}3,87 \pm 0,51 \\
p<0,001\end{array}$ & $\begin{array}{c}3,17 \pm 0,43 \\
p<0,001 \\
p 1>0,05\end{array}$ & $\begin{array}{c}6,89 \pm 0,69 \\
p<0,001 \\
p 1<0,01 \\
p 2<0,001\end{array}$ & $1,04 \pm 0,24$ \\
\hline
\end{tabular}

Примітка. За наявності достовірних відмінностей порівняно з показниками: $\mathrm{p}$ - контрольної групи, р1 - хворими на ХГС, р2 - хворими на ВІЛ-інфекцію.

Однак, найзначніше збільшення СРБ спостерігалося у хворих на ко-інфекцію ВІЛ/ХГС, порівняно з хворими на ХГС і ВІЛ-інфрекцію (мал. 1).

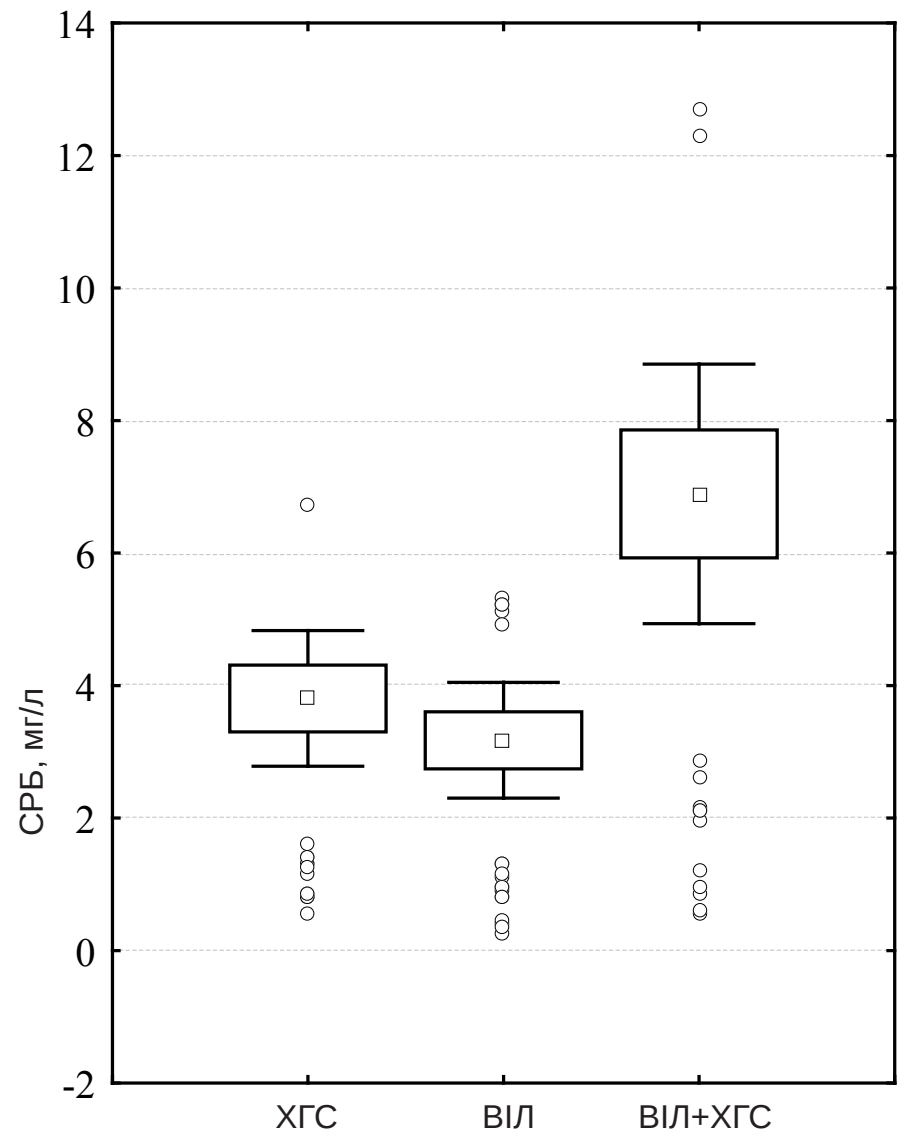

Мал. 1. Вміст СРБ у сироватці крові ВІЛ-інфрікованих осіб, хворих на ХГС і ко-інфекцію ВІЛ/ХГС.

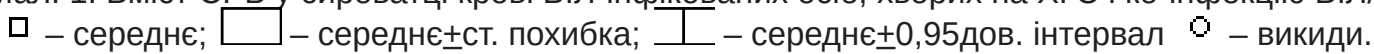

Вміст СРБ у ВІЛ-інорікованих осіб залежно від клінічної стадії ВІЛ-інфекції представлено в табл. 2. Виявлено достовірне збільшення рівня СРБ, порівняно 3 контролем, у ВІЛ-інорікованих осіб усіх кл. ст., але не дивлячись на тенденцію до підвищення його вмісту від стадії до стадії, він не виявив достовірного зв'язку 3 тяжкістю захворювання ( $>>0,05)$. 


\section{ОРИГІНАЛЬНІ ДОСЛІДЖЕННЯ}

Таблиця 2

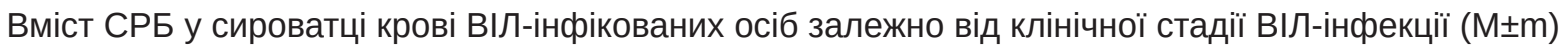

\begin{tabular}{|c|c|c|c|c|}
\hline \multirow[b]{2}{*}{ Показник } & \multicolumn{3}{|c|}{ Клінічна стадія ВІЛ-інфекції } & \multirow{2}{*}{$\begin{array}{c}\text { Контрольна група } \\
(\mathrm{n}=32)\end{array}$} \\
\hline & $\begin{array}{c}2 \text { кл. ст. } \\
(\mathrm{n}=11)\end{array}$ & $\begin{array}{c}3 \text { кл. ст. } \\
(\mathrm{n}=13)\end{array}$ & $\begin{array}{c}4 \text { кл. ст. } \\
(\mathrm{n}=11)\end{array}$ & \\
\hline СРБ, мг/л & $\begin{array}{c}3,02 \pm 0,80 \\
p<0,05\end{array}$ & $\begin{array}{c}3,09 \pm 0,60 \\
p<0,01 \\
p 1>0,05\end{array}$ & $\begin{array}{c}3,45 \pm 0,80 \\
p<0,01 \\
p 1>0,05 \\
p 2>0,05\end{array}$ & $1,04 \pm 0,24$ \\
\hline
\end{tabular}

Примітка. За наявності достовірних відмінностей порівняно з показниками: $\mathrm{p}$ - контрольної групи, р1 - хворими 2 кл. ст., р2 - хворими 3 кл. ст.

Вміст СРБ у хворих на ко-інфекцію ВІЛ/ХГС залежно від клінічної стадії ВІЛ-інфекції представлено в табл. 3. Дослідивши залежність вмісту СРБ від кл. ст. ВІЛ-інфекції у хворих на ко-інфекцію ВІЛ/ХГС, виявлено

достовірне збільшення вмісту СРБ у пацієнтів усіх кл. ст. хвороби від контролю, але також не виявлено достовірної різниці $(p>0,05)$ між рівнем СРБ і кл. ст. хвороби.

Таблиця 3

Вміст СРБ у сироватці крові хворих на ко-інфрекцію ВІЛ/ХГС залежно від клінічної стадії ВІЛ-інфрекції (Мะm)

\begin{tabular}{|c|c|c|c|c|}
\hline \multirow[b]{2}{*}{ Показник } & \multicolumn{3}{|c|}{ Клінічна стадія ВІЛ-інфрекції } & \multirow{2}{*}{$\begin{array}{c}\text { Контрольна група } \\
(\mathrm{n}=32)\end{array}$} \\
\hline & $\begin{array}{c}2 \text { кл. ст. } \\
(\mathrm{n}=11)\end{array}$ & $\begin{array}{c}3 \text { кл. ст. } \\
(\mathrm{n}=13)\end{array}$ & $\begin{array}{c}4 \text { кл. ст. } \\
(\mathrm{n}=11)\end{array}$ & \\
\hline СРБ, мг/л & $\begin{array}{c}7,07 \pm 1,50 \\
p<0,001\end{array}$ & $\begin{array}{c}6,97 \pm 1,90 \\
p<0,05 \\
p 1>0,05\end{array}$ & $\begin{array}{c}7,12 \pm 1,50 \\
p<0,001 \\
p 1>0,05 \\
p 2>0,05\end{array}$ & $1,04 \pm 0,24$ \\
\hline
\end{tabular}

Примітка. За наявності достовірних відмінностей порівняно з показниками: $р$ - контрольної групи, р1 - хворими 2 кл. ст., р2 - хворими 3 кл. ст.

Досліджено залежність вмісту СРБ від наявності фріброзу печінки у хворих на ХГС і ко-інфекцію ВІЛ/ХГС (табл. 4). Рівень СРБ у хворих на ХГС без ознак фріброзу печінки (за METAVIR) дорівнював $(1,52 \pm 0,32) \mathrm{мг/л,} \mathrm{а} \mathrm{у}$ хворих із наявністю фріброзу печінки $(4,35 \pm 0,66)$ мг/л. Отже, виявлено достовірну різницю між вмістом СРБ у хворих без фріброзу та з наявністю фріброзу печінки у хворих на ХГС (t=3,88; $\mathrm{p}<0,001)$. Дослідження вмісту СРБ у хворих на ко-інфрекцію ВІЛ/ХГС також встановило достовірне підвищення рівня СРБ у хворих з наявністю фріброзу печінки (за METAVIR), ніж у хворих із відсутністю фріброзу ( $t=3,27 ; p<0,001)$.

Досліджено залежність вмісту СРБ від генотипу HCV у хворих на ХГС і ко-інфекцію ВІЛ/ХГС. Так, вміст СРБ підвищувався у хворих на ХГС і склав $(3,07 \pm 0,62)$ мг/л у пацієнтів із 1b генотипом HCV i $(5,31 \pm 0,83) \mathrm{mr/л} \mathrm{-} \mathrm{у}$ хворих із За генотипом. Отже, виявлено достовірно більш високий рівень СРБ у хворих на ХГС 3 За генотипом вірусу $(t=2,15 ; p<0,05)$.

У хворих на ко-інфекцію ВІЛ/ХГС також вміст СРБ збільшувався та становив $(4,17 \pm 0,95)$ мг/л у пацієнтів iз 1 b генотипом HCV i $(8,97 \pm 1,50)$ мг/л - у хворих із За генотипом (табл. 4). Встановлено достовірно більш високий рівень СРБ у хворих із За генотипом $\mathrm{HCV}(\mathrm{t}=2,7$; p<0,01). Можливо, це пов'язано з тим, що саме 3-й генотип HCV викликає вірусіндукований стеатоз печінки та IP [11].

СРБ є предиктором розвитку серцево-судинних розладів, але найбільше діагностичне та прогностичне значення має поєднане його визначення $з$ показниками ліпідного обміну [4]. При дослідженні ліпідного спектру визначено, що $3 \mathrm{X}$ у досліджених пацієнтів не мав достовірної різниці 3 аналогічним показником осіб контрольної групи $(4,41 \pm 0,79)$ ммоль/л та дорівнював: $(4,13 \pm 0,11)$ ммоль/л у ВІЛ-інфікованих осіб, а у хворих на ХГС і коінфекцію ВІЛ/ХГС - $(4,12 \pm 0,18)$ і $(4,35 \pm 0,15)$ ммоль/л відповідно. У досліджених пацієнтів, порівняно 3 контролем, відзначалося достовірне зниження вмісту лПВщ. Так, у ВІЛ-інфікованих осіб вміст лПВщ склав $(1,21 \pm 0,07)$ ммоль/л, у хворих на ХГС - $(1,08 \pm 0,09)$ ммоль/л і ко-інфекцію ВІЛ/ХГС - $(1,04 \pm 0,14)$ ммоль/л, а в осіб контрольної групи $(1,47 \pm 0,03)$ ммоль/л. КА був підвищеним у всіх хворих і становив $(2,72 \pm 0,19)$ ум. од. у ВІЛ-інфікованих осіб і $(3,72 \pm 0,39)$ та $(3,14 \pm 0,36)$ ум. од. у хворих на ХГС і коінфекцію ВІЛ/ХГС відповідно порівняно з контролем $(2,12 \pm 0,04)$ ум. од. 


\section{ОРИГІНАЛЬНІ ДОСЛІДЖЕННЯ}

Таблиця 4

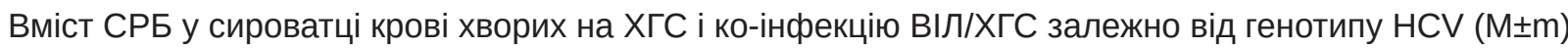

\begin{tabular}{|c|c|c|c|c|}
\hline \multirow{2}{*}{ Показник } & \multicolumn{3}{|c|}{ ХГС } & \multicolumn{2}{|c|}{ Ко-інфекція ВІЛ/ХГС } \\
\cline { 2 - 5 } & \multicolumn{4}{|c|}{ Генотип HCV } \\
\cline { 2 - 5 } & $\begin{array}{c}1 \mathrm{~b} \\
(\mathrm{n}=20)\end{array}$ & $\begin{array}{c}3 \mathrm{a} \\
(\mathrm{n}=13)\end{array}$ & $\begin{array}{c}1 \mathrm{~b} \\
(\mathrm{n}=14)\end{array}$ & $\begin{array}{c}3 \mathrm{a} \\
(\mathrm{n}=20)\end{array}$ \\
\hline СРБ, мг/л & $3,07 \pm 0,62$ & $5,31 \pm 0,83$ & $4,17 \pm 0,95$ & $8,97 \pm 1,50$ \\
\hline
\end{tabular}

При вивченні кореляційного зв'язку між СРБ і показниками ліпідного обміну виявлено, що СРБ має пряму кореляцію з КА ( $r=0,45 ; p<0,05)$ і зворотну з ЛПВЩ $(-0,35 ; p<0,05)$ у хворих на ко-інфекцію ВІЛ/ХГС, що свідчить про діагностичне та прогностичне значення даного показника для оцінки ризику розвитку ССЗ.

\section{Висновки}

1. Встановлено достовірне підвищення вмісту СРБ у сироватці крові ВІЛ-інфрікованих осіб, хворих на ХГС і ко-інфекцію ВІЛ/ХГС.

2. У ВІЛ-інфрікованих осіб і хворих на ко-інфекцію ВІЛ/ ХГС не встановлено достовірного зв'язку між вмістом СРБ і клінічною стадією ВІЛ-інфекції.

3. Вміст СРБ у хворих на ХГС і ко-інфекцію ВІЛ/ХГС з фріброзом печінки був вірогідно вище, ніж у хворих без оріброзу.

4. Виявлено вищий рівень СРБ у пацієнтів із За генотипом HCV у хворих на ХГС і ко-інфекцію ВІЛ/ХГС порівняно $3 \mathrm{lb}$ генотипом.

5. Проведення кореляційного аналізу виявило, що СРБ має прямий кореляційний зв'язок 3 КА $(r=0,45)$ i зворотний з ЛПВЩ $(-0,35)$ у хворих на ко-інфекцію ВІЛ/ ХГС.

\section{Література}

1. Вельков В.В. Прокальцитонин и С-реактивный белок в современной лабораторной диагностике / В.В. Вельков // Лабор. диагностика. - 2010. - № 4. - С. 39-76.

2. Гусев Д.Е. Роль С-реактивного белка и других маркеров острой фразы воспаления. / Д.Е. Гусев, Е.Г. Пономарь // Клин. медицина. - 2006. - № 2. - С. 25-30.

3. Shoelson S.E. Inflammation and insulin resistance. / S.E. Shoelson, J. Lee, A.B. Goldfine // J. Clin. Invest. - 2006. - N 11. - P. 1793-1801.

4. Вельков В.В. С-реактивний белок - «золотой маркер», многозначительний и незаменимый. Новое в клинической лабораторной диагностике атерогенеза: С-реактивний белок, холестерины, аполипопротеины / В.В. Вельков, - Пущино, 2005. - 110 с

5. Is C-reactive protein an independent risk factor for essential hypertension? / [L.E. Bautista, P. Lopez-Jaramillo, L.M. Vera et al.] / J. Hypertension. - 2001. - N 19. - P. 857-861.

6. Joint effect of C-reactive protein and glycated hemoglobin in predicting future cardiovascular events of patients with advanced atherosclerosis / [M. Schillinger, M. Exner, J. Amighi et al.] // Circulation. - 2003. - Vol. 108, N 19. - P. 2323-2328.

7. Вельков В.В. Сочетанное измерение уровней гликозилированного гемоглобина и С-реактивного белка в оценке риска осложнений сахарного диабета / В.В. Вельков // Лабор. диагностика. - 2008. - № 3 (45). - С. 67-72.

8. Ferranti S.D. C-reactive protein: a nontraditional serum marker of cardiovascular risk / S.D. Ferranti // Cardiovasc. Pathol. - 2007. Vol. 16, N 1. - P. 14-21

9. Козько В.М. Стан показників ліпідного обміну у ВІЛінфрікованих осіб, хворих на ХГС і ко-інфекцію ВІЛ/ХГС / В.М. Козько, К.В. Юрко, Г.О. Соломенник // Гепатологія - 2014. - № 4 (26). C. 33-39.

10. Зосимов А.Н. Системный анализ в медицине // А.Н. Зосимов. - Харьков: Торнадо, 2000. - 82 с.

11. Persico M. Steatosis as a co-factor in chronic liver diseases / M. Persico, A. Iolascon // World J. Gastroenterol. - 2010. - Vol. 16 N 10. - P. 1171-1176

\section{DIAGNOSTIC VALUE OF DETERMINATION OF C-REACTIVE PROTEIN IN HIV- INFECTED PERSONS, PATIENTS WITH CHRONIC HEPATITIS C AND CO- INFECTION HIV/HCV}

V.M. Kozko, K.V. Yurko, H.O. Solomennyk, A.A. Adeyemi SUMMARY. The article defines the content of $C$-reactive protein (CRP) in HIV-infected persons, patients with chronic hepatitis $C$ and co-infection with HIV/HCV. Research CRP that was conducted in 107 patients, including patients with chronic hepatitis C - 36, HIVinfection - 35, and co-infection with HIV/HCV - 36. Found a significant increase $(p<0.001)$ CRP content in HIV-infected persons, patients with chronic hepatitis $C$ and co-infection with HIV/HCV. It was found significantly higher levels of CRP in patients with genotype $3 \mathrm{a} \mathrm{HCV}$ infection in patients with chronic hepatitis $C(p<0.05)$ and co-infection of HIVIHCV $(p<0.01)$. No significant association was found between the content of CRP and clinical stage of HIV infection $(p>0,05)$ in HIV-infected persons and patients co-infected with HIVIHCV. It was detected credible link between high CRP content, presence of liver fibrosis $(p<0.001)$ in patients with chronic hepatitis $C$ and co-infected with HIV/HCV.

Key words: chronic hepatitis C, HIV-infection, coinfection of HIV/HCV, C-reactive protein.

Отримано 23.03.2015 p. 